\title{
PEMBENTUKAN KONSEP DIRI SATUAN PASPAMPRES RI
}

\author{
Melani Kurniasih Sormin $^{1 *}$ dan Ilham Prisgunanto ${ }^{2}$ \\ ${ }^{1}$ LSPR Communication and Business Institute, Jakarta - Indonesia \\ ${ }^{2}$ Perguruan Tinggi Ilmu Kepolisian (PTIK), Jakarta - Indonesia \\ *melanisrgr97@gmail.com
}

\begin{abstract}
The situation and facts where PASPAMPRES is an elite unit containing selected and qualified soldiers who have certain skills and privileges to be able to carry out Presidential VVIP security duties. The results showed that individual PASPAMPRES personnel have thoughts and self-assessment of quality and are superior, have a favorable opportunity for promotion compared to other unit personnel. This study aims to determine how the formation of self-concept in the personnel of the PASPAMPRES. A strict personnel admission selection where not all TNI soldiers can pass and have the desired qualifications make PASPAMPRES personnel called superior and elected personnel. The reason this research was conducted was to find out how this situation had its own impact on the self-concept of the selected PASPAMPRES personnel. The theory used is the Symbolic Interactionism theory by George Herbert Mead, Self-Concept and Group Thought Theory. This research methodology uses a constructivism paradigm with a qualitative approach and data collection techniques using interviews. The focus of this research focuses on how the mind, self, and society as well as the climate of the PASPAMPRES unit can influence the formation of personnel self-concept.
\end{abstract}

Keywords: self concept; paspampres; organizational climate

\begin{abstract}
Abstrak
Situasi dan fakta dimana PASPAMPRES adalah suatu kesatuan elite yang berisikan prajurit pilihan dan berkualitas serta memiliki keahlian dan keistimewaan tertentu untuk dapat menjalankan tugas pengamanan VVIP Kepresidenan. Penelitian ini bertujuan untuk mengetahui pembentukan konsep diri pada personil satuan PASPAMPRES yang dilatarbelakangi seleksi penerimaan personil yang ketat dimana tidak semua prajurit TNI dapat lulus dan memiliki kualifikasi yang di kehendaki menjadikan personil PASPAMPRES disebut personil yang unggul dan terpilih. Alasan penelitian ini dilakukan untuk mengetahui bagaimana keadaan tersebut memberikan dampak tersendiri bagi konsep diri personil PASPAMPRES yang terpilih. Teori yang digunakan adalah teori Interaksionisme Simbolik oleh George Herbert Mead, Konsep Diri dan Teori Pemikiran Grup. Metodologi penelitian ini menggunakan paradigma konstruktivisme dengan pendekatan kualitatif serta teknik pengumpulan data menggunakan wawancara. Fokus penelitian ini mengerucut pada bagaimana pikiran, diri, and masyarakat serta iklim satuan PASPAMPRES dapat memberikan pengaruh dalam pembentukan konsep diri personil. Hasil penelitian menunjukkan bahwa personil PASPAMPRES secara individu memiliki pemikiran dan penilaian akan diri yang berkualitas dan lebih unggul, memiliki kesempatan yang menguntungkan untuk promosi jabatan dibandingkan personil satuan lain.
\end{abstract}

Kata Kunci: konsep diri; paspampres; iklim organisasi

\section{PENDAHULUAN}

Aspek vital VVIP negara memiliki posisi yang sangat penting dalam suatu pemerintahan kenegaraan. VVIP (Very-Very Important Person) yang dimaksudkan (PASPAMPRES, n.d.) adalah Presiden RI beserta keluarga, Wakil Presiden beserta keluarga, dan tamu Negara setingkat kepala Negara atau kepala pemerintahan, beserta keluarga yang mana memerlukan sebuah bentuk pengamanan extra. Dalam rangka pengamanan dan protokoler telah adanya satu kesatuan pengamanan Presiden dan Wakil Presiden di Indonesia yang dinamakan PASPAMPRES.

PASPAMPRES adalah pasukan khusus yang muncul akibat pengaruh dari sebuah proses sejarah bangsa yang panjang dalam 
rangka menjaga, mengamankan, serta mengawal keamanan kepala negara dalam menjalankan tugas. Perubahan dan perkembangan zaman serta situasi politik mempengaruhi sistem organisasi PASPAMPRES itu sendiri.

$$
\text { Menjadi bagian dari kesatuan }
$$

PASPAMPRES tidaklah mudah, diperlukan banyak latihan dan kesiapan matang, mulai dari segi fisik, mental, dan juga kecakapan dalam segala situasi dan kondisi. Sesuai Pataka PASPAMPRES "Setia Waspada" yang dilansir dalam website resmi (PASPAMPRES, n.d.) mengemukakan bahwa lambang PASPAMPRES secara keseluruhan mengandung makna yang kuat dan berhubungan tugas dan tanggung jawab PASPAMPRES dalam keseharian. PASPAMPRES terjun langsung berada di samping kepala negara guna menjaga keselamatan jiwa VVIP yang merupakan representasi dari harkat dan martabat bangsa di mata dunia.

Pengamanan yang dilakukan berupa pengamanan fisik Presiden dan Wakil jarak dekat, pengamanan dari segi konsumsi, dan juga pengamanan melalui armada transportasi, iring-iringan konvoi dalam lalu lintas (pergerakan pindah tempat dari satu lokasi menuju lokasi berikutnya) (Arinuryadi, 2018).

Dilansir berita Tempo dijelaskan proses menjadi anggota PASPAMPRES perlu banyak penyaringan ketat (Tarigan, 2015). Menurut Wakil Komandan PASPAMPRES Brigadir Jenderal TNI Maruli Simanjuntak, anggota PASPAMPRES adalah orang-orang terpilih dari masing-masing matra angkatan, yakni; Angkatan Udara, Angkatan Laut, dan Angkatan Darat serta Kepolisian sehingga rangkaian tahapan penyaringannya cukup ketat.

Seleksi awal dimulai dari tes psikologi terutama menyoal tingkat ketenangan, kecepatan, dan keberanian dalam pengambilan keputusan. Tes ini digunakan untuk mengetahui kondisi psikis dari calon anggota PASPAMPRES. Salah satu alasan karena dalam keseharian bertugas akan memegang senjata sebagai alat pengamanan.
Di samping itu, tes fisik juga diperhitungkan, karena PASPAMPRES harus memiliki kemampuan beladiri serta kuat berlari dan memiliki kesehatan yang prima. Di samping itu penampilan termasuk aspek penting bagi PASPAMPRES karena akan menjadi sorotan mata setiap orang yang melihat rangkaian acara kepresidenan baik nasional maupun internasional (Tarigan, 2015). Selain tes fisik, ada banyak syarat tes lain. Syarat diartikan sebagai tuntutan atau kualifikasi (Wulandari, 2016)

Syarat seleksi wajib diikuti oleh para pengawal utama Presiden, selain mengetahui kondisi psikis juga terdapat tes IQ guna mengetahui tingkat cepat tanggap dari personil, dimana seluruh test psikologi ini dirangkum dalam psikotest (Latifah, 2018). PASPAMPRES sangat dekat dengan bahaya dan mengandung resiko yang luar biasa besar, sehingga diperlukan kesiapan yang prima antara fisik dan mental serta kesiapan lainnya (Nugroho, 2017).

Citra PASPAMPRES di mata masyarakat merupakan suatu hal penting yang perlu dijaga. Citra PASPAMPRES yang sudah terbentuk dan tertanam dalam diri masingmasing personil anggapan diri dan status juga kewibawaan yang disandang. Berada dalam suatu kesatuan yang sangat sensitif akan sorotan dan pantauan masyarakat maupun aspek lain membentuk pembawaan diri tiap personil mulai dari sikap dan tingkah laku yang terlihat pada tiap personil akan dirinya.

Konsep diri adalah seperangkat persepsi yang relatif stabil yang dipercaya orang mengenai diri mereka sendiri. Setiap manusia saat mengekspresikan identitas dirinya akan berhubungan dengan konsep diri yang mereka Yakini yang dilansir dari (West, R., \& Turner, 2017). Sebuah konsep diri yang secara tidak sadar sudah terbentuk dalam diri personil TNI menjadi bagian yang ingin diteliti. Menurut (Riswandi, 2013: 64) dalam (Widiarti, 2017), bahwa konsep diri manusia terbentuk atas dasar komunikasi yang terjalin dengan orang lain sehingga muncul pemahaman tentang diri 
sendiri dimana konsep diri merupakan faktor penentu komunikasi kita dengan orang lain.

Dijelaskan juga dalam (Widiarti, 2017) menurut Brooks bahwa konsep diri merupakan refleksi atau persepsi diri terhadap perasaan dan pandangan tentang diri kita, bisa dalam bentuk psikologis, sosial, dan fisik. Konsep diri manusia secara jelas dapat terdiferensiasi dan terstruktur, dimana konsep diri akan berkembang dan mengalami perubahan seiring dengan waktu (Hall\&Lindzey, 1978, 499) dalam (Widiarti, 2017).

Pada (Yudit Oktaria Kristiani Pardede, 2011) Konsep diri adalah gambaran deskriptif dan evaluatif individu mengenai diri sendiri; penelitian atau penaksiran mengenai diri sendiri, ataupun cara seseorang memandang dirinya sendiri. Menurut Baldwin dan Holmes (dalam Calhoun dan Acocella 1995), faktor pembentuk konsep diri remaja adalah orangtua, kawan sebaya, masyarakat, dan belajar. Sampel dalam penelitian ini adalah seorang anak jalanan yang sudah putus hubungan dengan keluarganya, dan berpartisipasi penuh di jalanan, baik secara sosial maupun ekonomi. Dari hasil analisis data, diketahui bahwa secara umum, konsep diri yang terbentuk pada diri subyek adalah konsep diri yang negatif. Hal ini terlihat dari beberapa bagian diri subyek yang sebagian besar memandang dirinya secara negatif. Hal tersebut juga dapat diakibatkan oleh beberapa faktor yang membentuk konsep diri subyek ke arah yang negatif, yakni orangtua, kawan sebaya, dan masyarakat.

Dalam (Masduki Asbari, Agus Purwanto, 2020) Budaya organisasi atau iklim organisasi merupakan salah satu factor penting untuk membangun sumber daya manusia melalui aspek perubahan sikap dan perilaku, yang diharapkan mampu menyesuaikan diri dengan tantangan yang sedang berjalan dan yang akan datang (S, 2019) Iklim organisasi merupakan suatu kekuatan sosial yang tidak tampak, yang dapat menggerakkan orang-orang dalam suatu organisasi untuk melakukan aktivitas kerja. Iklim organisasi yang kuat mendukung tujuan-tujuan perusahaan ataupun instansi pemerintahan. Iklim organisasi memiliki peranan penting dalam mengelola suatu organisasi karena merupakan persepsi yang sama dan utuh tentang makna hakiki kehidupan bersama dalam organisasi.

Sedangkan dalan (Hutagalung Inge dan Ritonga Rajab, 2018) Iklim organisasi merupakan keadaan di sebuah organisasi, tempat setiap anggotanya saling berinteraksi, membatasi diri, ataupun berinteraksi satu sama lain sehingga dapat meningkatkan kualitas kerja sama dan peningkatan kinerja anggota organisasi. Iklim organisasi yang kondusif akan mendorong para anggota organisasi untuk saling berinteraksi satu sama lain yang dapat meningkatkan komitmen pada organisasi. Komitmen organisasi akan menjadi indikator kepuasan kerja karyawan, bersama efektivitas komunikasi interpersonal yang dilakukan. Di sisi lain, keterbukaan komunikasi dalam sebuah organisasi akan membuat suasana kerja menjadi kondusif dan nyaman. Dengan membiasakan diri untuk berketrampilan komunikasi yang baik di tempat kerja, maka karyawan akan mencapai kepuasan kerja.

Penelitian pada Pembentukan Konsep Diri merupakan kasus yang awam serta cukup banyak diteliti di seluruh dunia. Ruang lingkup penelitian Pembentukan Konsep Diri sebelumnya pernah diteliti oleh Rajesh Kumar, Roshan Lal, dan Beenu Varma dalam artikel jurnal berjudul "To Study the Anxiety Level and Self Concept among Army Personnel". Selain itu, penelitian kedua yang dilakukan oleh $\mathrm{Hj}$.Indirawaty, Syamsuddin AB menggunakan teori interaksionisme simbolik dalam artikel jurnal berjudul "Nurse Interaction With Clients In Communication Therapeutic (Study Analysis of Symbolic Interactionism Hospital South Sulawesi)".

Dapat disederhanakan bahwa dalam penelitian ini ingin mengetahui kedalaman sebuah simbol dan interaksi yang sudah menyatu pada personil PASPAMPRES dalam keseharian selama bersosialisasi dengan sesama personil sehingga menghasilkan sebuah konsep diri yang mereka yakini dalam diri personil masing-masing. Konsep diri yang terbentuk merupakan hasil keyakinan akan 
suatu makna dan simbol serta dikembangkan melalui interaksi sosial dalam satuan PASPAMPRES sehingga melekat pada diri personil secara individu dan terbawa saat proses komunikasi sosial dalam masyarakat (Mulyana, 2016).

Penelitian bertujuan untuk mengetahui konsep diri yang terbentuk dalam konteks komunikasi organisasi dalam satuan PASPAMPRES berdasarkan interaksi simbolik yang terjadi? dan interaksi satuan PASPAMPRES dalam konteks komunikasi organisasi di antara sesama mereka berdasarkan iklim komunikasi PASPAMPRES?

Penelitian ini juga mempunyai rumusan permasalahan yang menjadi konsentrasi utama dapat disimpulkan dengan Bagaimana konsep diri yang terbentuk dalam konteks komunikasi organisasi dalam satuan PASPAMPRES berdasarkan interaksi simbolikyang terjadi dan. Bagaimana interaksi PASPAMPRES dalam konteks komunikasi organisasi diantara sesame berdasarkan iklim komunikasi PASPAMPRES.

Manfaat dari penelitian ini agar bisa diharapkan dapat memberikan sumbangsih kebijakan dan keputusan strategis terhadap model konsep diri dan interaksi pada personil PASPAMPRES khususnya dalam sudut pandang pikiran (mind), diri (self), dan masyarakat (society).

\section{METODOLOGI PENELITIAN}

Penelitian ini menggunakan metode analisis data kualitatif, dijelaskan (Pongtiku, A., Rerey, V. H., Kayame, R., Soeprapto, T., \& Resubun, 2017) penelitian dengan metode pengolahan data kualitatif digunakan untuk mencari kebenaran dan pengetahuan dengan lebih menitikberatkan pada sudut pandang subyektif yang ditentukan oleh peneliti. Disebutkan juga bahwa masalah penelitian adalah fokus utama, dimana terdapat dimensidimensi yang menjadi perhatian utama untuk diteliti, dalam hal ini dimensi yang dimaksud adalah ialah pikiran (mind), diri (self) and masyarakat (society).

Peneliti akan mengumpulkan data dengan menggunakan beberapa teknik. Dalam keperluan menganalisis Interaksionisme Simbolik dalam komunikasi organisasi personil PASPAMPRES untuk melihat pembentukan konsep diri akan dilakukan. Pengumpulan data, yakni data primer melalui wawancara dengan pihak terkait guna mendapatkan jawaban terkini dan langsung dari narasumber tanpa adanya unsur pengaruh aspek lain, serta data sekunder, yakni dari penggunaan dokumen yang sudah ada sebelumnya.

Hasil penelitian kelak mengedepankan tingkat ketepatan dan ketelitian dibandingkan dengan kondisi yang sebenarnya (Yusuf, 2017). Teknik pengumpulan data yang digunakan peneliti yang termasuk dalam golongan data primer adalah wawancara.

Rosaliza menyatakan wawancara merupakan salah satu cara pengumpulan data yang sering digunakan dalam penelitian sosial, dimana informan atau responden dan peneliti melakukan aksi tatap muka berbicara saling bertukar informasi keperluan data primer yakni berisikan fakta, kepercayaan, perasaan, keinginan, dan lain sebagainya dalam rangka pemenuhan tujuan penelitian.

Peneliti ini juga mengumpulkan data sekunder dari studi dokumen (Bungin, 2010) dalam (Nilamsari, 2014) menyatakan bahwa metode dokumenter adalah salah satu metode yang tidak dapat dipisahkan dari penelitian kualitatif dikarenakan adanya kesadaran dan pemahaman baru yang berkembang bagi peneliti bahwa data banyak tersimpan dalam bentuk dokumen dan artefak, dimana tingkat kredibilitas banyak ditemukan pada pemanfaatan dokumen yang ada.

Peneliti menganalisa seberapa berkembangnya PASPAMPRES ditinjau dari pemberitaan media, berita online, opini publik dan lain sebagainya, serta dari dokumen yang sudah ada. Penelitian ini dilakukan dengan menggunakan 4 narasumber, yakni; 2 orang anggota PASPAMPRES, 1 orang TNI biasa dan 1 orang adalah keluarga anggota PASPAMRES.

Untuk menganalisa data yang diperoleh melalui wawancara dan studi dokumen, peneliti berusaha menyajikan data secara sistematis, 
ringkas dan sederhana agar mudah dipahami. Peneliti mendeskripsikan data kualitatif dengan cara menyusun dan melakukan pengelompokkan data yang sudah ada, sehingga responden dapat mengetahui data dengan gambaran nyata (Mulyana, 2016).

\section{HASIL DAN PEMBAHASAN}

Interaksionisme Simbolik karya George Herbet Mead menjelaskan mengenai Mind, Self, and Society. Dijelaskan bahwa individu memberikan reaksi terhadap aksi dalam lingkungan sosial dengan merefleksikan tentang apa yang menjadi bagian dari makna yang mereka yakini serta menentukan sikap dan perbuatan yang mereka pikirkan (Syarifuddin, A., \& Raditya, 2016). Dalam teori ini membahas bagaimana diri individu (self) dan masyarakat (society) dijabarkan melalui interaksi dengan orang lain dimana partisipasi dan komunikasi sangat berperan penting (Ahmadi, 2008).

Lebih lanjut disebarkan, pikiran kemampuan menggunakan simbol yang bermakna sosial yang sama, sehingga manusia bisa mengembangkan pikiran melalui interaksi dengan manusia lain di sepanjang hidupnya (West, R., \& Turner, 2017). Benak atau pikiran ialah fokus individual dari proses komunikasi dalam bentuk perilaku linguistik dari individu. Pikiran muncul dalam proses sosial yang terusmenerus berlanjut dan sifatnya dinamis yang akan menjadi pengalaman manusia (Mead, 2018).

Jelasnya Mind Personil PASPAMPRES yang memiliki bentuk pemikiran yang unik. Pemikiran akan sosok diri lebih bagus dan lebih keren dibanding prajurit tidak diperlihatkan secara langsung namun dinyatakan dengan pernyataan secara terselubung yang memperlihatkan upaya menyombongkan diri dengan mengeluarkan pernyataan hangat dan kooperatif. Pada sisi pemikiran akan kekuasaan yang dimiliki, personil PASPAMPRES berpegang pada prosedur tugas sebagai titik acuan sehingga mereka berkuasa penuh pada hal-hal yang berkaitan pada pengamanan VVIP kepresidenan dibandingkan prajurit TNI lainnya, maupun satuan pengamanan lainnya karena mengacu pada prinsip kerja zero mistakes.

Dari segi pemikiran promosi jabatan, kenyataan di lapangan akan menunjukkan jabatan di dalam organisasi PASPAMPRES adalah sebuah batu loncatan dapat menjabat ke posisi yang jauh lebih baik karena didasari pada posisi terdahulu PASPAMPRES yaitu; berisikan prajurit handal dan terpilih sehingga dikategorikan personil berkualitas dan kompeten untuk dapat menjalankan tugas dan tanggung jawab selanjutnya yang lebih baik.

Pemikiran akan lebih mudah mendapatkan promosi jabatan nyatanya jelas terlihat pada perjalanan karier para prajurit TNI eks PASPAMPRES yang kini berada pada jabatan atau posisi strategis. Namun, personil PASPAMPRES memilih dengan mengutarakan suatu bentuk pernyataan kebohongan dalam sisi positif karena personil PASPAMPRES tidak mau memperlihatkan keangkuhan demi kebaikan bersama, diri sendiri dan nama baik kesatuan. Pemikiran hangat dan memposisikan diri sama dengan personil satuan lain adalah bentuk sikap personil PASPAMPRES untuk tetap bersikap netral dan tidak sombong agar tidak ada persaingan karier antar sesama prajurit TNI.

Kesimpulan sikap ini didukung dengan artikel yang ditulis oleh Ahmad (2017) yang menyatakan bahwa dengan segala sanjungan dan pujian yang dilontarkan personil PASPAMPRES didasari pada keunggulan yang mereka miliki tidak menjadikan mereka tinggi hati dan lupa daratan.

Self personil PASPAMPRES, self menurut Ahmadi (2008) berkaitan dengan kepribadian reflektif yang dapat diartikan lewat interaksi dengan orang lain, self juga bagian dari anggapan mengenai siapa diri kita. Pemahaman akan konsep diri dapat terlihat pada perkembangan diri yang hanya terjadi lewat pengambilan peran, sehingga kita harus memiliki peran sebagai orang lain untuk dapat merefleksikan diri.

$$
\text { Self personil PASPAMPRES }
$$
mengedepankan penilaian diri mereka secara 
individu, ialah unggul dan berkualitas. Hal tersebut didasari pada kualifikasi yang mereka miliki dan tes yang sudah dilewati sehingga terpilih sebagai bagian dari pasukan elite satuan PASPAMPRES, karena tidak semua prajurit memiliki kesempatan yang sama (Asril, S., Erdianto, K., Ihsanuddin., Tashandra, 2018).

Perjalanan berbagai macam tes serta keahlian yang tidak semua prajurit miliki menjadikan mereka individu yang berkualitas dan juga mumpuni untuk dapat mengemban tugas melakukan pengamanan VVIP Presiden dan Wakil Presiden. Seiring berjalannya waktu, terpaan latihan teknik pengamanan yang selalu diasah, kegiatan pengamanan kepresidenan yang dilakukan sebagai rutinitas, serta polapola kerja yang dituntut satuan PASPAMPRES membuat personil secara individu terlatih, tanggap, dan peka terhadap kewaspadaan ancaman dalam menjalankan setiap tugas dan tanggung jawab. Hal demikian secara tidak langsung menunjukkan ke masyarakat bahwa mereka adalah pasukan hebat dan memiliki kualitas yang baik.

Keandalan dari personil PASPAMPRES diperlihatkan lewat penampilan selama bertugas, kesigapan, cara berpakaian dan kewibawaan yang mereka tunjukan saat menjalankan tugas (Pradana, 2017). Kehebatan personil ditunjukkan melalui perilaku dan bahasa tubuh (Farah, 2018).

Berdasarkan tugas pokok pengamanan yang dikerjakan personil PASPAMPRES disegani masyarakat karena mereka memiliki kesetiaan kerja tak kenal waktu untuk mengamankan Presiden dan wakil Presiden dari serta mengesampingkan urusan pribadi dan mengutamakan kewajiban mengabdi untuk bangsa dan negara.

Society personil PASPAMPRES, terbentuk atas dasar interaksi yang terjadi antar individu yang menggunakan berbagai macam simbol yang signifikan, yaitu bahasa. Komunikasi yang terjadi mempunyai makna dan gerakan, dimana manusia harus menafsirkan dan menentukan makna mereka sendiri dari setiap gerakan tersebut.
Pada akhirnya, proses komunikasi membutuhkan interpretasi manusia (Suhartono, 2016). Saat melakukan interaksi dengan orang lain, makna bersama terjadi melalui pengambilan peran dimana pelaku komunikasi, yaitu manusia harus menempatkan dirinya pada posisi orang lain.

Dengan kata lain, manusia memberikan tanggapan akan dirinya sebagaimana orang lain menanggapi diri mereka sendiri. Perilaku sosial terjadi saat individu memberi respon terhadap orang lain dan saat individu manusia sudah tergabung dalam perilaku orang lain atau menjadi bagian dalam suatu tempat atau bagian dari sebuah organisasi (Ahmadi, 2008). Setiap aktivitas yang dilakukan oleh individu pada hakekatnya tidak akan berjalan dengan baik dan lancar tanpa adanya proses komunikasi yang efektif, sehingga dengan demikian anggota PASPAMPRES pun dalam menyikapi setiap tanggapan yang ditujukan kepada dirinya akan menghasilkan sebuah respon dalam bentuk komunikasi baik verbal maupun non verbal. Bentuk respon yang positif dapat terlihat dengan jelas melalui rangkaian komunikasi yang terjalin (Paramithasari, N., \& Kartika, 2017).

Berdinas dalam satuan PASPAMPRES, anggapan orang lain terhadap mereka secara individu cenderung berdasarkan apa yang dipikirkan masyarakat ketika melihat mereka dikaitkan satuan dimana mereka berdinas. Anggapan tersebut secara tidak langsung memberi pengaruh pada bagaimana mereka memandang diri berdasarkan masyarakat memandang mereka secara individu dan memandang mereka bagian dari PASPAMPRES itu sendiri.

Secara garis besar, Society pada Personil PASPAMPRES memberikan pengaruh pada penilaian mereka akan diri sebagai individu. Doktrin jiwa korsa sebagai prajurit TNI berperan penting menentukan sikap dan sifat pasukan dalam menjalankan kehidupan sehari-hari.

Diakui, bahwa PASPAMPRES merupakan satuan elite karena memberikan personilnya kesempatan menguntungkan bagi 
jenjang perjalanan karier yang bagus, namun hal ini tidak dapat dinyatakan secara lisan melainkan diyakini secara tersirat. Begitupun sebaliknya, rasa sebagai diri yang gemilang menjadi panutan banyak orang pun sesungguhnya dirasakan akan tetapi pasukan PASPAMPRES mengutamakan rasa jiwa korsa sehingga memposisikan diri mereka sama dengan prajurit satuan lain.

Tidak menganggap diri mereka sebagai sosok yang melebihi prajurit satuan lainnya, meski secara nyata keistimewaan dan kelebihan personil PASPAMPRES terlihat. Personil PASPAMPRES memilih tidak mengemukakan diri secara pribadi melainkan mengedepankan pendapat universal sebagai prajurit TNI yang menjunjung tinggi jiwa korsa dengan rasa sepernasib dan solid tanpa memandang perbedaan dari segi kualitas diri serta keahlian yang dimiliki personil PASPAMPRES secara pribadi yang mana sesungguhnya keistimewaan personil PASPAMPRES dapat dilihat secara kasat mata perbedaannya (Hendra, 2019).

Dalam kerja, Iklim komunikasi PASPAMPRES. Jelas komunikasi adalah sebuah proses interaksi yang di dalamnya memiliki unsur feedback atau umpan balik. Respon umpan balik berupa pengiriman ulang pesan oleh penerima ke sumber (Hapsari, 2018).

Tiaguri (1968) dalam Muhammad (2005) dalam (Hapsari, 2018) menyatakan iklim komunikasi organisasi terdapat kualitas komunikasi yang abadi pada lingkungan internal organisasi tersebut, dimana hal ini dialami oleh anggota organisasi dan mempengaruhi tingkah laku dan sikap mereka hingga kepada motivasi kerja.

Hapsari menyatakan bahwa

"Keberlangsungan hidup suatu organisasi tidak dapat terlepas dari iklim dalam organisasi, yang menggambarkan adanya suasana yang ada dalam organisasi. Dalam menggambarkan suasana dalam organisasi dapat dilihat dari iklim organisasi dan iklim komunikasi yang ada dalam organisasi" (Hapsari, 2018).

Satuan PASPAMPRES memiliki pola komunikasi organisasi, dimana alur komunikasi antara atasan dan bawahan berguna dalam penyampaian tugas dan juga arahan-arahan berkaitan dengan jalannya proses pengamanan VVIP Presiden dan Wakil Presiden yang baik. Di dalam satuan PASPAMPRES memiliki tingkatan organisasi, yakni; 4 Grup dan Detasemen.

Proses penyampaian pesan dilaksanakan melalui tingkatan mulai dari paling bawah, yakni; regu, pleton, kompi, batalyon, dimana masing-masing tingkatan diatasi terlebih dahulu oleh komandan tingkatan tersebut. Bila terdapat kesulitan akan disampaikan ke tingkatan atas (Maruli, 2020).

Dalam menjalankan kerja dalam sebuah organisasi dibutuhkan komunikasi yang optimal antara atasan dan bawahan. Etika berkomunikasi menjadi hal yang penting untuk diperhatikan agar mencapai tujuan organisasi. Dalam Kamus Besar Bahasa Indonesia, interaksi diartikan sebagai hal yang berhubungan, saling mempengaruhi, dan merupakan hubungan sosial yang dinamis (Kamus Besar Bahasa Indonesia Online, n.d.).

Dalam kesatuan PASPAMRES, yang berisikan lebih dari satu matra dimana personilpersonilnya merupakan gabungan dari Angkatan Darat, Angkatan Laut, dan juga Angkatan Udara. Ketiga matra ini bergabung menjadi satu kesatuan dalam rangka pengamanan VVIP presiden dan wakil presiden. Komunikasi yang terjalin memberi dampak pada kelancaran tugas.

Interaksi Atasan Bawahan satuan PASPAMPRES berjalan dengan baik sesuai dengan ketentuan yang telah ditetapkan. Tahapan penyampaian informasi dan pesan disampaikan secara berjenjang didasari pada tingkatan jabatan dan posisi yang ada pada struktur organisasi yakni sesuai jalur komando. Pola komunikasi atasan dan bawahan yang ada dalam PASPAMPRES pun memiliki seni dimana difokuskan kepada makna dari isi pesan tersebut. Perbedaan pola dan gaya komunikasi terlihat jelas berbeda pada saat penugasan operasional serta saat pembinaan karena makna pesan pun berbeda. Keberagaman matra tidak menjadi penghambat alur dalam berkomunikasi 
dan hambatan kerja karena setiap penugasan sudah memiliki prosedur tersendiri dan masingmasing personil dituntut untuk bekerja secara profesional dan berada dalam aturan yang ada. Keberagaman matra justru menjadi cermin kesolidan mereka sebagai TNI dalam pelaksanaan tugas dan tanggung jawab, terkhusus PASPAMPRES solid dalam menjalankan tugas pengamanan VVIP presiden dan wakil presiden.

Kesimpulan diperkuat pernyataan Ma'ruf Amin selaku Wakil Presiden Republik Indonesia saat mengadakan kunjungan ke Markas Komando PASPAMPRES bahwa PASPAMPRES adalah pasukan solid dan profesional yang tidak diragukan kesiapannya untuk menjadi perisai hidup presiden dan wakil presiden (Prihatin, 2019).

$$
\text { Suasana dalam Organisasi }
$$

PASPAMPRES komunikatif yang relatif baik dan tegas kepada aturan serta prosedur yang berlaku. Organisasi PASPAMPRES mengedepankan rasa loyal kepada atasan dan professional kerja dimana keberagaman matra serta egosentris matra tidak dinomorsatukan dalam aspek penugasan kerja.

PASPAMPRES memberikan perhatian kepada personil dengan mengapresiasi tiap bentuk prestasi personilnya tanpa memandang latar belakang matra yang disandang. Selaras dengan pesan Jokowi selaku Presiden Republik Indonesia yakni prajurit TNI tidak boleh terjebak oleh egosentris matra pada hal apapun itu dan harus mampu bersinergi kerja dengan kementerian dan lembaga dalam membangun negara, serta kontribusi prajurit TNI serta jajaran sangat berarti dalam kemajuan NKRI (Anwar, 2019).

Suasana bebas dari egoisme matra menjadikan satuan PASPAMPRES bercitarasa seperti sebuah matra sendiri, dimana personil PASPAMPRES cenderung bangga memposisikan diri dengan sebutan satuan PASPAMPRES terlepas dari menyebutkan asal matra mereka. Doktrin kuat PASPAMPRES yakni pasukan elite pengamanan kepresidenan menjadikan personilnya bangga akan status mereka dan memposisikan hal tersebut sangat dominan seperti matra tersendiri bagi personil PASPAMPRES.

Memori dari organisasi PASPAMPRES menurut Crowder dalam (Suryani, 2007:41) adalah suatu hal yang mengaitkan diri terhadap gambaran pengalaman masa lalu, dimana informasi akan hal tersebut digunakan sekarang. Penggunaanya yakni dengan proses pemerolehan dan pemunculan kembali informasi di masa lampau (Fatmasari, 2014).

Berkaitan dengan penelitian ini, resimen Tjakrabirawa menurut Hakim (2018) adalah PASPAMPRES terdahulu dengan sebutan PASPAMPRES generasi pertama. Tjakrabirawa yang merupakan cikal bakal PASPAMPRES adalah pasukan elite yang berisikan prajurit TNI terbaik berasal dari keempat matra yaitu matra Darat, matra Laut, dan Matra Udara, Kepolisian.

Pasukan ini memiliki tugas sama dengan PASPAMPRES yakni melakukan pengamanan VVIP presiden (Fahmi, 2019). Namun masa lalu Tjakrabirawa yang terlibat dalam peristiwa G30S/PKI pada aksi penculikan sejumlah jenderal TNI membuat Tjakrabirawa dibubarkan oleh Ir. Soekarno (Fahmi, 2019).

Memori masa lalu Tjakrabirawa menurut (Matanasi, 2019) dalam Fotaleno (2017) masih melekat sampai sekarang dimana dikenal sebagai pasukan penculik dan pembunuh para jenderal jika dikaitkan dengan peristiwa G30S/PKI, sehingga menjadi salah satu faktor acuan PASPAMPRES untuk menjadi lebih baik hingga saat ini.

Memori PASPAMPRES yang tidak luput dari Tjakrabirawa membuat satuan ini berbenah diri ke arah lebih baik. Seiring perkembangan jaman, perubahan dilakukan dalam rangka memperlancar tugas pengamanan VVIP presiden dan wakil presiden dengan prinsip utama zero mistakes sebagai bentuk persiapan dan kewaspadaan akan ancaman.

Citra masa lalu PASPAMPRES dijadikan pijakan sebagai tolak ukur masa kini dan juga masa yang akan datang agar setiap hal yang kurang baik tidak terulang. Tentu saja untuk mengubah citra buruk bisa dilakukan 
dengan memberdayakan Marketing Public Relations yang berkorelasi kuat terhadap pembentukan citra yang ada (Christria, 2016). Hal ini didukung dengan PASPAMPRES kini mengubah diri ke arah yang lebih baik yang bertujuan memudarkan citra masa lalu yang kurang baik (Pragota, 2017).

Penelitian ini menjelaskan pertama, self personil PASPAMPRES mengedepankan penilaian bahwa diri mereka secara individu ialah unggul dan berkualitas. Hal tersebut didasari pada kualifikasi yang mereka miliki dan keberhasilan melewati serangkaian tes sehingga terpilih sebagai bagian dari pasukan elite satuan PASPAMPRES, karena tidak semua prajurit memiliki kesempatan yang sama (Asril, S., Erdianto, K., Ihsanuddin., Tashandra, 2018).

Keberhasilan lulus tes serta keahlian khusus yang dimiliki personil PASPAMPRES menjadikan mereka sebagai individu berkualitas dan mumpuni untuk dapat mengemban tugas melakukan pengamanan VVIP presiden dan wakil presiden jarak dekat maupun jauh. Seiring berjalannya waktu, kegiatan pengamanan dan pola kerja yang dituntut oleh satuan PASPAMPRES membuat mereka secara individu menjadi terlatih dan tanggap akan setiap tugas dan tanggung jawab yang mereka emban.

Berpikir secara optimal sebagai pasukan terpilih dan unggul mendorong personil secara individu melakukan hal yang terbaik dalam segala kondisi dan situasi apapun baik tersulit bagi mereka dalam menjalankan tugas pengamanan (Fauziyah, 2011). Hal demikian secara tidak langsung menunjukkan kepada masyarakat bahwa mereka adalah pasukan hebat dan memiliki kualitas baik.

Kehebatan ditunjukkan oleh personil PASPAMPRES bukan dengan ucapan atau perkataan semata melainkan melalui penampilan selama bertugas, kesigapan dan kewaspadaan saat bertugas, cara berpakaian yang berbeda dan menarik perhatian serta kewibawaan yang mereka tunjukan saat menjalankan tugas (Pradana, 2017). Kehebatan personil PASPAMPRES ditunjukkan melalui perilaku dan bahasa tubuh (Farah, 2018).

$$
\text { Kedua, Society Personil }
$$

PASPAMPRES memberikan pengaruh pada penilaian mereka akan diri mereka sebagai individu. Namun doktrin jiwa korsa sebagai prajurit TNI berperan penting menentukan sikap dan sifat pasukan dalam menjalankan kehidupan sehari-hari. Pada kenyataannya, PASPAMPRES merupakan satuan yang elite karena memberikan personilnya kesempatan menguntungkan bagi jenjang perjalanan karier yang bagus.

Hal demikian tidak dapat dinyatakan secara lisan melainkan diyakini secara tersirat. Begitupun sebaliknya, rasa sebagai diri yang gemilang menjadi panutan banyak orang pun sesungguhnya dirasakan akan tetapi pasukan PASPAMPRES mengutamakan rasa jiwa korsa sehingga memposisikan diri mereka sama dengan prajurit satuan lain. Tidak menganggap diri sebagai sosok yang melebihi prajurit satuan lainnya meskipun secara nyata keistimewaan dan kelebihan personil PASPAMPRES terlihat dengan signifikan.

Personil PASPAMPRES memilih untuk tidak mengemukakan pendapat mereka secara pribadi melainkan mengedepankan pendapat universal sebagai prajurit TNI yang menjunjung tinggi jiwa korsa dengan rasa sepernasib dan solid tanpa memandang perbedaan dari segi kualitas diri serta keahlian yang dimiliki personil PASPAMPRES secara pribadi yang mana keistimewaan personil PASPAMPRES dapat dilihat secara kasat mata perbedaannya (Hendra, 2019).

Ketiga, Iklim komunikasi di satuan PASPAMPRES dilihat dari segi Interaksi Atasan - Bawahan berjalan dengan baik sesuai dengan ketentuan yang telah ditetapkan. Tahapan penyampaian informasi dan pesan secara berjenjang didasari tingkatan jabatan dan posisi yang ada pada struktur organisasi yakni sesuai jalur komando.

Pola komunikasi atasan dan bawahan yang ada dalam PASPAMPRES pun memiliki seni dimana difokuskan kepada makna dari isi pesan tersebut, terbagi atas penyampaian pesan 
pada operasional tugas kerja dan penyampaian pesan dalam rangka pembinaan anggota.

Iklim komunikasi personil PASPAMPRES memiliki ukuran pada sisi ketegasan dan keseriusan komunikasi berdasarkan makna dan tujuan pesan tersebut disampaikan. Keberagaman matra tidak menjadi penghambat alur dalam berkomunikasi dan hambatan kerja karena setiap penugasan sudah memiliki prosedur tersendiri dan masingmasing personil dituntut untuk bekerja secara profesional dan berada dalam aturan yang ada.

Keberagaman matra justru menjadi cermin kesolidan mereka sebagai TNI dalam pelaksanaan tugas dan tanggung jawab, terkhusus PASPAMPRES solid dalam menjalankan tugas pengamanan VVIP presiden dan wakil presiden. Kesiapannya untuk menjadi perisai hidup presiden dan wakil presiden (Prihatin, 2019).

Keempat, suasana organisasi PASPAMPRES menunjukkan komunikatif yang relatif baik dan tegas kepada aturan serta prosedur yang ada. Organisasi PASPAMPRES lebih mengedepankan rasa loyal kepada atasan dan profesional kerja dalam keberagaman matra serta egosentris matra tidak dinomorsatukan dalam aspek penugasan kerja. PASPAMPRES memberikan perhatian kepada personil dengan mengapresiasi setiap bentuk prestasi yang dihasilkan oleh personilnya tanpa memandang latar belakang matra yang disandang.

Suasana bebas dari egoisme matra menjadikan satuan PASPAMPRES bercita rasa seperti sebuah matra sendiri, dimana personil PASPAMPRES cenderung bangga memposisikan diri mereka dengan sebutan satuan PASPAMPRES terlepas dari menyebutkan asal matra mereka. Hal ini sesuai bahwa organisasi yang baik sangat tergantung pada perhatian antar anggota di dalamnya juga partisipasi yang tinggi dan akan memberikan iklim keterbukaan pada organisasi (Putri, 2018).

Doktrin kuat PASPAMPRES adalah pasukan elite pengamanan kepresidenan menjadikan personilnya bangga akan status dan memposisikan hal tersebut sangat dominan seperti matra tersendiri bagi personil PASPAMPRES.

Kelima, Memori PASPAMPRES yang tidak luput dari Tjakrabirawa membuat satuan ini memperbaiki diri ke arah yang lebih baik. Komunikasi erat kaitannya dengan perilaku dan pengalaman kesadaran manusia (Sukendar, 2017). Sehingga hal tersebut memberi kesinambungan akan komunikasi terdahulu Tjakrabirawa dengan PASPAMPRES masa kini.

Perubahan ada seiring perkembangan jaman melalui berbagai cara. Salah satunya dari komunikasi yang berdampak pada perilaku yang dilakukan dalam rangka memperlancar tugas pengamanan VVIP presiden dan wakil presiden. Salah satu bentuk persiapan akan ancaman yang akan datang kapan saja dalam bentuk apa saja.

Citra masa lalu PASPAMPRES dijadikan pijakan sebagai tolak ukur masa kini agar setiap hal yang kurang baik tidak terulang di masa kini bahkan masa yang akan datang serta mengadaptasi perubahan jaman agar mengetahui setiap perkembangan yang ada dari segala aspek kehidupan yang berkaitan dengan pengamanan objek vital VVIP presiden dan wakil presiden. Dimulai dari mempersiapkan sumber daya manusia yang baik dan kompeten dan secara alat-alat pengamanan yang ditingkatkan ke sisi yang lebih canggih dan modern. PASPAMPRES mengeluarkan penyataan bahwa mereka kini tengah mengubah diri ke arah yang lebih baik bertujuan memudarkan citra masa lalu yang kurang baik (Pragota, 2017).

\section{SIMPULAN}

Dengan demikian dapat disimpulkan, bahwa dalam mengetahui dan memahami kepribadian diri dan interaksi yang terjadi pada anggota satuan PASPAMPRES dapat melalui konsep diri personil PASPAMPRES yang dimana berdasarkan teori interaksi simbolik dimana Mind Personil PASPAMPRES telah terbentuk bersandar pada makna yang sudah diyakini secara bersama dari setiap interaksi 
sosial yang terjadi dalam satuan PASPAMPRES. Personil PASPAMPRES memiliki pikiran mereka adalah personil lebih bagus dan keren daripada prajurit satuan lain, personil PASPAMPRES pun mempunyai pikiran bahwa mereka mempunyai kekuasaan yang lebih serta memiliki pemikiran akan percaya diri yang tinggi terhadap kesempatan mendapatkan promosi jabatan yang strategis dibanding personil satuan lain. Pembentukan konsep diri personil PASPAMPRES berdasarkan Iklim satuan PASPAMPRES sangat berperan penting. Hal demikian terlihat pada Interaksi atasan dan bawahan, yakni antar komandan, atau dengan anggotanya berdasarkan jalur komando atau struktur organisasi dimana faktor gaya kepemimpinan menjadi salah satu faktor penentu bagaimana suasana interaksi akan terbentuk nantinya.

Dalam satuan PASPAMPRES, tahapan penyampaian informasi dan pesan disampaikan secara berjenjang didasari pada tingkatan jabatan dan posisi yang ada. Ada seni penyampaian yang difokuskan kepada makna dari isi pesan tersebut antara lain penyampaian pesan pada operasional tugas kerja dan penyampaian pesan dalam rangka pembinaan anggota. Letak perbedaan terlihat pada sisi ketegasan komandan dan keseriusan komunikasi berdasarkan makna dan tujuan pesan tersebut disampaikan.

\section{DAFTAR PUSTAKA}

Ahmadi, D. (2008). Interaksi Simbolik: Suatu Pengantar. Jurnal Mediator. Interaksi Simbolik: Suatu Pengantar. Jurnal Mediator, 9(2), 301-316.

Anwar, A. (2019). Tiga Pesan Jokowi Kepada Prajurit TNI,Singgung Egosentris Matra.

Arinuryadi, R. (2018). Strategi Peningkatan Kemampuan Personel Pasukan Pengamanan Presiden (PASPAMPRES) Dalam Tugas Pengamanan Presiden dan Wakil Presiden Republik Indonesia. [Tesis Master, STIE Widya Wiwaha Yogyakarta].

Asril, S., Erdianto, K., Ihsanuddin., Tashandra, N. (2018). PASPAMPRES, Kisah Para
Perisai Hidup.

Christria, J. dan D. A. (2016). Pengaruh Marketing Public Relations Terhadap Citra Merek: Studi Pada Restoran Joe's Grill Swiss-Belhoteltle. Jurnal Coverage, 7.

Fahmi, Y. (2019). Tjakrabirawa, Si Elite Penjaga Presiden Sukarno yang Terseret G30S/PKI.

https://www.liputan6.com/news/read/407

0270/tjakrabirawa-si-elite- penjagapresiden-sukarno-yang-terseretg30spki\#\%0A

Farah. (2018). Perilaku Non-Verbal yang Bisa Membuat Kita Merasa Memiliki Power! https://psychology.binus.ac.id/2018/11/19 /perilakunon-verbal-yang-bisa-membuatkita-merasa-memiliki-power/

Fatmasari, Y. (2014). BAB II Kajian Pustaka A. Pengertian Memori. UIN.

Fauziyah, A. (2011). Dahsyatnya Kemauan, Cara Mulia Mengubah Penghalang Jadi Peluang. Penerbit Zaman.

Hapsari, E. D. . (2018). Iklim Komunikasi Organisasi Dalam Childhood Cancer Care (Studi Deskriptif Kualitatif Iklim Komunikasi Organisasi pada Komunitas Childhood Cancer Care di Rumah Sakit Dr.Moewardi Surakarta). Online, 4, 1832. http://aimijournal.com/

Hendra, Y. (2019). Spiral of Silence Theory Versus Perkembangan Masyarakat Sebuah Penjelasan dan Kritik Teori. Jurnal Simbolika: Research and Learning in Communication Study, 5(2), 106-117.

Hutagalung Inge dan Ritonga Rajab. (2018). Pengaruh Iklim Komunikasi dan Komitmen Organisasi Terhadap Kepuasan Kerja Pegawai Kecamatan XYZ Bekasi. Jurnal Kajian Komunikasi, 6, No. 2, 7284.

Kamus Besar Bahasa Indonesia Online. (n.d.). Definisi dampak.

Latifah, E. (2018). Ingin Jadi Paspampres? Ini Syarat-syaratnya. https://doi.org/5 November 2019

Masduki Asbari, Agus Purwanto, P. B. S. M. A. (2020). Pengaruh Iklim Organisasi dan 
Kepemimpinan Transformasional Terhadap Produktivitas Kerja Inovatif Pada Industri Manufaktur di Pati Jawa Tengah. 7, No 1 .

Matanasi, P. (2019). Tidak Semua Anggota Cakrabirawa Terlibat G30S. https://tirto.id/tidak-semua-anggotacakrabirawa-terlibat-g30s-eizq

Mead, G. . (2018). Mind, Self, Society. Penerbit Forum William Saputra.

Mulyana, D. (2016). Ilmu Komunikasi Suatu Pengantar. PT. Remaja Rodaskarya Offset.

Nilamsari, N. (2014). Memahami Studi Dokumen Dalam Penelitian Kualitatif. Wacana Volume, 13(2), 177-181. 13(2), 177-181.

Nugroho, W. (2017). Pengelolaan Logistik Satuan Guna Mendukung Tugas Pokok PASPAMPRES. Jurnal Prodi Strategi Dan Kampanye Militer, 3(2), 47-57.

Paramithasari, N., \& Kartika, R. (2017). Lima Kualitas Sikap Komunikasi Antar Pribadi oleh Unit Customer Complaint Handling PT BNI Life Insurance. Journal of Strategic Communication, 8(1), 1-11.

PASPAMPRES. (n.d.). Sejarah PASPAMPRES, Awal Kelahiran Paspampres.

Pongtiku, A., Rerey, V. H., Kayame, R., Soeprapto, T., \& Resubun, Y. (2017). Metode Penelitian Kualitatif Saja. Nulisbuku.com.

Pradana, R. . (2017). Penampilan Paspampres Zaman Now Menurut Jokowi. https://kabar24.bisnis.com/read/20171218 /15/719316/penampilanpaspampreszaman-now-menurut-jokowi

Pragota, A. (2017). Riwayat Prajurit Perisai Presiden.

https://kumparan.com/kumparannews/ria wayatprajurit-perisai-presiden-daritjakrabirawa-ke-paspampres/full

Prihatin, I. U. (2019). Tinjau Markas Paspampres, Ma'ruf Amin Berikan Pesan di Atas Kanvas. https://www.merdeka.com/peristiwa/tinja umarkas-paspampres-maruf-aminberikan-pesan-di-atas-kanvas.html

Putri, D. P. dan D. K. (2018). Prinsip-Prinsip Human Relations Dalam Pelaksanaan Komunikasi Organisasi di Kementerian Komunikasi dan Informatika. Jurnal Coverage, 8 no. 2 .

S, M. dan M. (2019). Pengaruh Budaya Organisasi Terhadap Semangat Kerja Pegawai Pada Dinas Kesehatan Kabupaten Pelalawan. Jurnal Niara, 11(2), 118-124. https://doi.org/10.31849/nia.v11i2.2111

Sosiologis. (2018). Teori Interaksionisme Simbolik. http://sosiologis.com/teoriinteraksionisme-simbolik

Suhartono. (2016). Definisi Interaksi Simbolik. http://spi.uinalauddin.ac.id/index.php/201 6/10/31/interaksi-simbolik/

Sukendar, M. . (2017). Psikologi Komunikasi: Teori dan Praktik. Deepublish.

Syarifuddin, A., \& Raditya, A. (2016). Interaksi Simbolik Antara Shadow Dengan Anak Autis di "Sekolah Kreatif" Surabaya. Jurnal Analisa.

Tarigan, M. (2015). Mau Jadi Paspampres, Harus Ganteng? Simak Syaratnya.

West, R., \& Turner, L. . (2017). Pengantar Teori Komunikasi Analisis dan Aplikasi E5. Salemba Humanika.

Widiarti, P. W. (2017). Konsep Diri (Self Concept) Dan Komunikasi Interpersonal Dalam Pendampingan Pada Siswa SMP Se-Kota Yogyakarta. Informasi Kajian Ilmu Komunikasi, 47(1), 135-148.

Wulandari, Y. (2016). Buku Pintar Praktis Bahasa Indonesia Praktis \& Lengkap! Wacana Media.

Yudit Oktaria Kristiani Pardede. (2011). KONSEP DIRI ANAK JALANAN USIA REMAJA. Jurnal Psikologi, 1 .

Yusuf, A. . (2017). Metode Penelitian Kuantitatif, Kualitatif, \& Penelitian Gabungan. Kencana Prenadamedia Group. 